\title{
RANCANG BANGUN PENGATURAN RUANG MEETING DENGAN ALGORITMA DIVIDE AND CONQUER PADA HOTEL AMALIA BANDAR LAMPUNG
}

\author{
Wahyu Susilo $^{1}$, Sulyono ${ }^{2}$, Rio Kurniawan ${ }^{3}$ \\ 1,2,3 Jurusan Teknik Informatika, Fakultas Ilmu Komputer \\ Informatics And Business Institute Darmajaya \\ Jl. Z.A. Pagar Alam No.93, Bandar Lampung, Indonesia 35142, Telp.(0721)787214. \\ Fax. (0721)700261 \\ e-mail:sulyono@darmajaya.ac.id,riokurniawan@darmajaya.ac.id
}

\begin{abstract}
Recording of meeting rooms is carried out by the Amalia Hotel marketing division by using calendar events and this takes a long time. The marketing division wants an application that is able to analyze meeting room packages that are ordered most quickly and accurately. To determine the meeting package that is most ordered at Amalia Hotel, the marketing division requires several criteria including the usage period, the name of the meeting room and meeting package. The divide and conquer method is applied by way of dividing the data of the use of meeting packages into two groups, determining the greatest value of each group, and combining the largest values of each group together to find the greatest value.

The application applied is in accordance with the needs of the marketing division. Evidently when looking for packages that are most ordered from 140 data borrowing meeting packages, the application can display the percentage of meeting packages that are the most in order within $0.0018 \mathrm{~ms}$. Applications can be developed using other sorting methods such as bubble sort and selection sort that can solve problems without dividing the problem into two groups first.
\end{abstract}

Keywords: Application, Meeting Room, Meeting Room Package

\begin{abstract}
ABSTRAK
Pencatatan ruang meeting dilakukan oleh divisi marketing Hotel Amalia dengan menggunakan event calendar dan hal tersebut membutuhkan waktu yang lama. Divisi marketing menginginkan sebuah aplikasi yang mampu menganalisa paket ruang meeting yang paling banyak di order dengan cepat dan akurat. Untuk menentukan paket meeting yang paling banyak di order pada Hotel Amalia, divisi marketing membutuhkan beberapa kriteria diantaranya yaitu periode pemakaian, nama ruang meeting dan paket meeting. Metode divide and conquer diterapkan dengan cara, membagi data pemakaian paket meeting menjadi dua kelompok, menentukan nilai terbesar dari masing-masing kelompok, dan menggabungkan nilai terbesar dari masing-masing kelompok menjadi satu untuk mencari nilai terbesar.

Aplikasi yang diterapkan telah sesuai dengan kebutuhan divisi marketing. Terbukti saat mencari paket yang paling banyak di order dari 140 data peminjaman paket meeting,
\end{abstract}


aplikasi dapat menampilkan persentase paket meeting yang paling banyak di order dalam waktu 0,0018 ms. Aplikasi dapat dikembangkan dengan menggunakan metode sorting lainnya seperti bubble sort dan selection sort yang dapat menyelesaikan masalah tanpa membagi masalah menjadi dua kelompok terlebih dahulu.

Kata Kunci : Aplikasi, Ruang Meeting, Paket Ruang Meeting

\section{PENDAHULUAN}

Ruang meeting adalah salah satu fasilitas yang ditawarkan oleh Hotel Amalia untuk berbagai macam keperluan sesuai dengan kebutuhan pemesanan (tamu) seperti meeting ataupun sebagai tempat untuk melaksanakan pesta (party). Pencatatan peminjaman ruang meeting dilakukan oleh marketing dalam bentuk Banquete Event Order (BEO) yang akan diberikan kepada peminjam ruang meeting (tamu) dan pihak terkait (housekeeping, F\&B, Security, Receptionist dan operational manager). Pada periode tertentu tim marketing akan melakukan perhitungan manual dengan menggunakan event calendar untuk menganalisa peminjaman ruang meeting berdasarkan BEO yang sudah pernah dibuat sebelumnya dan hal tersebut membutuhkan waktu yang lama. Tim marketing menginginkan sebuah aplikasi yang mampu mempermudah untuk memasukkan data dan menganalisa peminjaman ruang meeting dengan waktu yang cepat.
Berdasarkan permasalahan yang ada diatas, maka memunculkan sebuah gagasan untuk membuat suatu media atau aplikasi yang dapat menganalisis paket ruang meeting yang paling banyak di order pada periode tertentu. Aplikasi pengaturan ruang meeting diharapkan mampu mempermudah pihak management untuk lebih menganalisa penggunaan ruang meeting dan paket ruang meeting yang paling banyak di order pada periode tertentu.

\section{METODE PENELITIAN}

\subsection{Metodologi Penelitian}

Metode penelitian yang digunakan adalah metode deskriptif. Untuk mendapatkan basis pengetahuan dibutuhkan proses pengumpulan data yang dapat diperoleh dengan studi literatur dan wawancara dengan pihak marketing Hotel Amalia dengan mengunjungi hotel (tempat menyewa ruang meeting), meminta data tentang nama ruang meeting, harga sewa dan 
contoh data tamu yang pernah meminjam ruang meeting di hotel tersebut.

\subsection{Pengetahuan Ruang Meeting Hotel Amalia}

Hotel Amalia memiliki lima buah ruang meeting yaitu Azalea, Catelya, Dahlia, Gladiol dan Hebras. Hotel Amalia memiliki empat buah paket meeting yaitu :

1. Paket Halfday. Maksimal 4 jam peminjaman ruang meeting include : 1x Coffee Break, 1x Lunch

2. Paket Fullday. Maksimal 8 jam peminjaman ruang meeting include : 2x Coffee Break, 1x Lunch/Dinner

3. Paket Wholeday. Maksimal 12 jam peminjaman ruang meeting include : 2x Coffe Break, 1x Lunch \& 1x Dinner

4. Paket Fullboard. Maksimal 12 jam peminjaman ruang meeting include : 2x Coffe Break, 1x Lunch \& $1 \mathrm{x}$ Dinner serta 1 Superior Room untuk 2 orang.

Pencatatan peminjaman ruang meeting dilakukan oleh marketing dalam bentuk Banquete Event Order (BEO) yang akan diberikan kepada peminjam ruang meeting (tamu) dan pihak terkait (housekeeping,F\&B, Security,
Receptionist dan operational manager). Pada periode tertentu tim marketing akan melakukan perhitungan manual untuk menganalisa peminjaman ruang meeting berdasarkan BEO yang sudah pernah dibuat sebelumnya. Misalnya untuk menganalisa berapa banyak Paket Halfday yang pernah diorder oleh tamu pada periode tertentu di ruang meeting Azalea, tim marketing akan mengumpulkan BEO ruang meeting Azalea dan menghitung jumlah Paket Halfdaynya.

\subsection{Menghitung Jumlah Paket Terbanyak yang Pernah di Order Penerapan Algoritma Divide and Conquer}

Untuk pencarian paket terbanyak dapat dilakukan dengan contoh sebagai berikut

Ruang Meeting : Gladiol

$$
\begin{array}{lll}
\text { - } & \text { Paket Halfday } & : 22 \text { buah } \\
\text { - } & \text { Paket Fullday } & : 5 \text { buah } \\
\text { - } & \text { Paket Wholeday } & : 5 \text { buah } \\
\text { - } & \text { Paket Fullboard } & : 0 \text { buah }
\end{array}
$$

Sesuai dengan skema umum algoritma Divide and Conquer maka penyelesaian mencari paket terbanyak dilakukan dengan cara :

1. Membagi Kelompok bilangan menjadi 2 bagian
22
5
50 
2. Mencari Nilai terbesar dari masing-masing kelompok
22

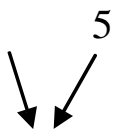

22

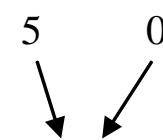

5
3. Menggabungkan 2 nilai terbesar manjadi 1 dan mencar nilai terbesar

22

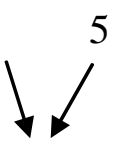

22

4. Maka paket yang banyak diminati adalah paket dengan order 22 buah yaitu Paket Halfday

Metode Pengembangan Perangkat Lunak ini dilakukan rekayasa perangkat lunak dimana prosesnya disebut dengan rekayasa sistem yang menerapkan System Development Life Cycle (SDLC) dengan model Waterfall. Penerapan SDLC dapat dilihat sebagai berikut :

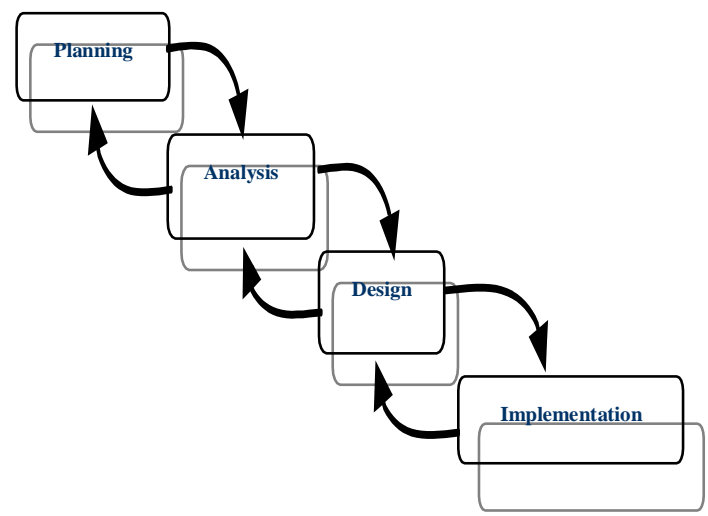

Gambar 2.2 Metode Pengembangan Perangkat Lunak Model WaterFall

\subsection{Perencanaan (Planning)}

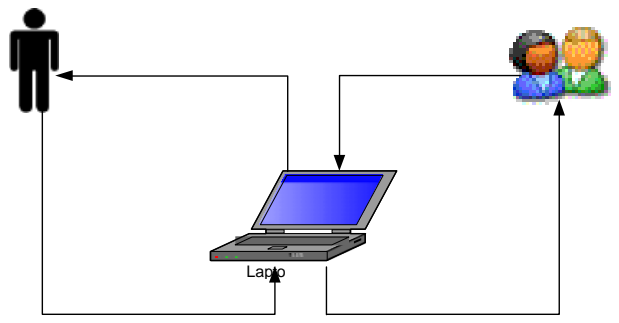

Gambar 2.3 Sistem yang akan dibuat

User menginputkan Banquete Event Order kedalam aplikasi dan dapat menggunakan aplikasi ini untuk menganalisa penggunaan ruang meeting yaitu mencari paket terbanyak yang diminati oleh tamu.

\subsection{Rancangan Struktur Database}

Relasi antar tabel pada penelitian ini sebagai berikut :

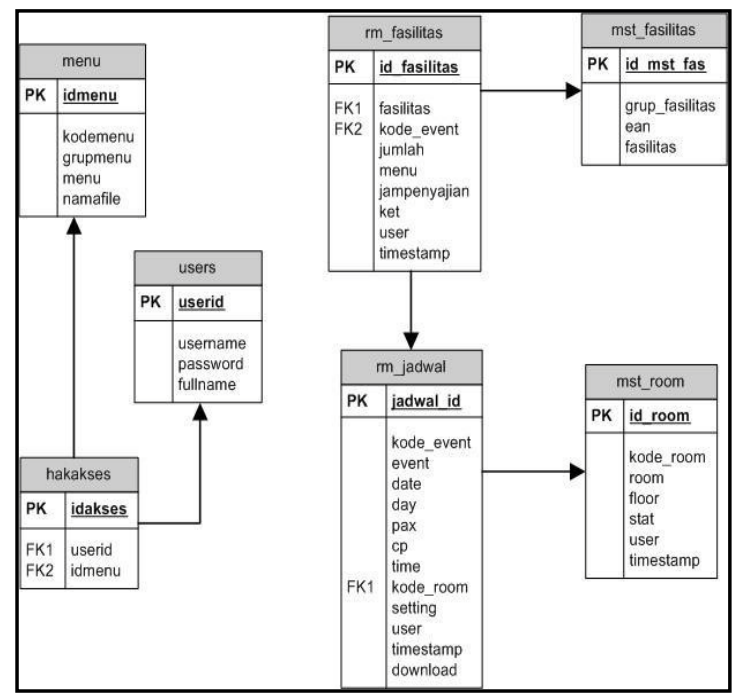

Gambar 2.7 Relasi Antar Tabel 


\section{HASIL DAN PEMBAHASAN}

\subsection{Implementasi Program}

Aplikasi ini dijalankan pada komputer stand alone dengan menginstal program aplikasi web server di komputer. Sebagai ganti domain situs, penulis menggunakan localhost.

Aplikasi ini diakses dengan menggunakan alamat http://localhost/magenta/ pada web browser. Yang terdiri dari beberapa halaman antara lain:

1. Halaman utama (index.php)

2. Halaman home (home.php)

3. Halaman master room

4. Halaman tambah jadwal

5. Halaman lihat jadwal

6. Halaman Print BEO

7. Halaman Analisa RM

Untuk mendapatkan hasil analisa digunakan algoritma Divide and Conquer sebagai berikut

\subsection{Testing dan Hasil Uji}

Pengujian pada aplikasi pengaturan ruang meeting yang sudah dibuat penulis menyatakan perangkat lunak yang diimplentasikan telah sesuai dengan spesifikasi kebutuhan pada bagian analisis dan perancangan. Hal ini dibuktikan dengan keberhasilan masing-masing subsistem melakukan apa yang menjadi spesifikasi seperti telah ditanyakan di
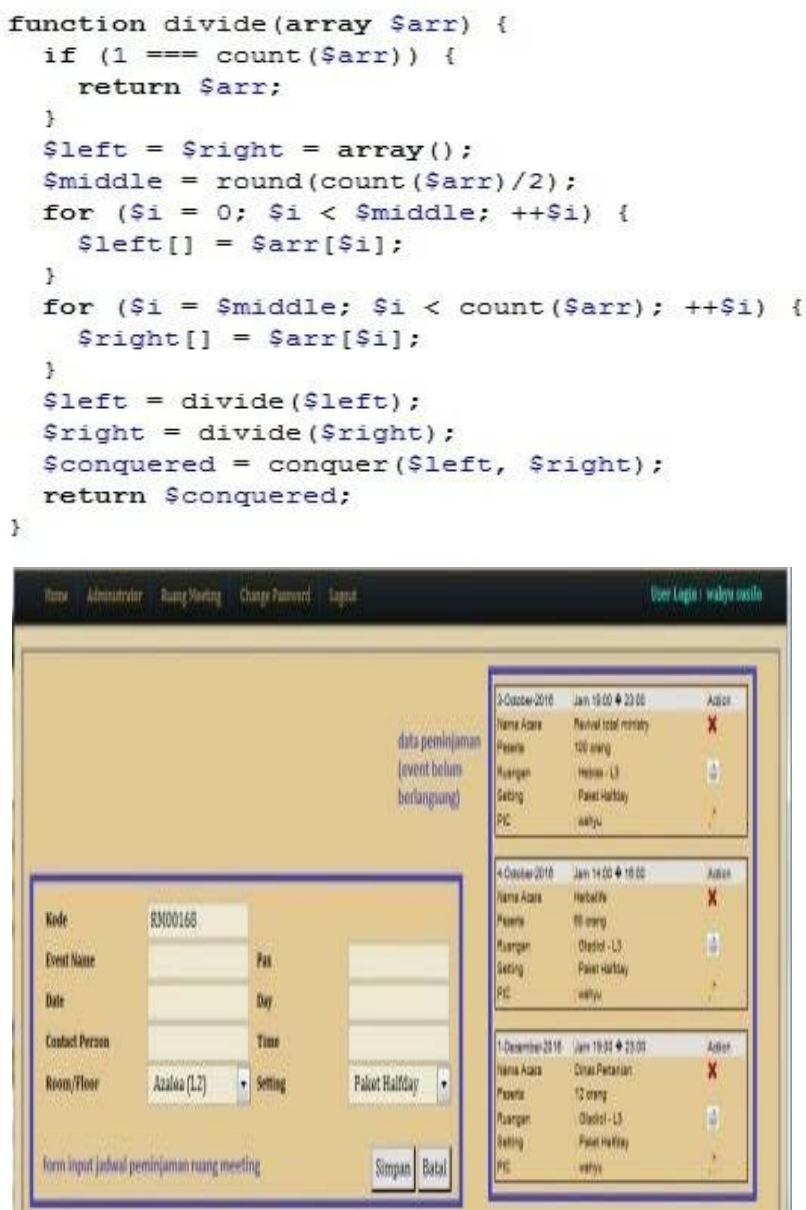

bagian hasil pengujian, sehingga proses yang terjadi telah dengan prosedur yang dispesifikasikan.

Tabel 3.1 Tabel Ceklist

Pengujian Aplikasi

\begin{tabular}{|c|c|c|c|}
\hline \multirow{2}{*}{ No } & \multirow{2}{*}{ Parameter Pengecekan } & \multicolumn{2}{|c|}{ Hasil } \\
\hline & & Sukses & Tidak \\
\hline 1 & Login aplikasi & $\sqrt{ }$ & - \\
\hline 2 & $\begin{array}{l}\text { Akses submenu di menu } \\
\text { ruang meeting }\end{array}$ & $\sqrt{ }$ & - \\
\hline 3 & $\begin{array}{l}\text { Input dan simpan master } \\
\text { ruang meeting }\end{array}$ & $\sqrt{ }$ & - \\
\hline 4 & $\begin{array}{l}\text { Input dan simpan tambah } \\
\text { jadwal }\end{array}$ & $\sqrt{ }$ & - \\
\hline 5 & $\begin{array}{l}\text { Input dan simpan tambah } \\
\text { pemakaian fasilitas }\end{array}$ & $\sqrt{ }$ & - \\
\hline 6 & $\begin{array}{l}\text { Cek Analisa Ruang } \\
\text { Meeting }\end{array}$ & $\sqrt{ }$ & - \\
\hline
\end{tabular}




\section{SIMPULAN}

Pencatatan peminjaman ruang meeting dilakukan oleh marketing dalam bentuk Banquete Event Order (BEO) yang akan diberikan kepada peminjam ruang meeting (tamu) dan pihak terkait (housekeeping, F\&B, Security, Receptionist dan operational manager). Pada periode tertentu tim marketing akan melakukan perhitungan manual dengan menggunakan event calendar untuk menganalisa peminjaman ruang meeting berdasarkan BEO yang sudah pernah dibuat sebelumnya dan hal tersebut membutuhkan waktu yang lama dan Aplikasi pengaturan ruang meeting dengan menggunakan algoritma divide and conquer dapat mempermudah divisi marketing dalam memasukkan data banquete event order dan menganalisa paket ruang meeting yang paling banyak di order pada periode tertentu secara otomatis dengan cepat dan akurat.

\section{DAFTAR PUSTAKA}

[1] Coronel, C., Morris, S., \& Rob, P. 2009. Database systems: Design, implementation, and management. Ninth edition. Course Technology Cengage Learning, USA.

[2] Madcoms. 2009. Langsung bisa membangun website profesional dengan adobe CS4, PHP \& MySQL. Andi, Yogyakarta.
[3] Munir,R.https://www.academia.ed u/8719785/Modul_11._Algoritma_ divide_and_conquer. Algoritma divide and conquer bahan kuliah IF3051 strategi algoritma Oleh: Rinaldi munir. Diakses 18 April 2016 20:50

[4] Simamarta, Janner. 2010. Rekayasa web. Yogyakarta : ANDI.

[5] Seebaluck, V., Naidoo, P. \& Ramseook Munhurrun, P. (2013). Meetings, incentives, conferences and exhibitions as a tourism development Strategy in mauritius. Global conference on business and financeproceedings. May8-3 (2013), 8(2), 354-364, ISSN 19419589, San Jose, Costa Rica. 